International Journal of Life Sciences
Available online at www.sciencescholar.us
Vol. 4 No. 3, December 2020, pages: $41-49$
e-ISSN: 2550-6986, p-ISSN: 2550-6994
https://doi.org/10.29332/ijls.v4n3.503

\title{
Tongkol (Euthynnus affinis) Fermentation on Organoleptics and Its Biochemistry
}

Ni Made Darmadi ${ }^{a}$, Dewa Gede Semarab ${ }^{\text {, I Made Kawan }}{ }^{c}$

Manuscript submitted: 9 September 2020, Manuscript revised: 18 October 2020, Accepted for publication: 27 November 2020

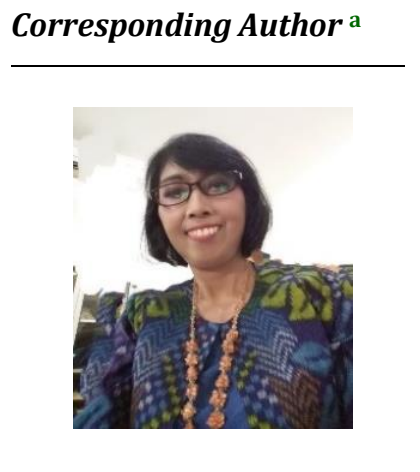

Keywords

bromelin;

euthynnus affiis;

fermentation;

free fatty acid;

papain;

\begin{abstract}
The technology to improve the quality of feed ingredients is fermentation. In general, all fermentation end products usually contain compounds that are simpler and easier to digest than the original ingredients. Tongkol fish can be fermented into Fermented Tongkol (Euthynnus affinis). The research method used was a completely randomized design with three treatments and three replications. The treatment used three types of ferment. Data were analyzed using ANOVA and LSD Advanced Test. The results showed that the best treatment was treatment using a combination of ferment 50\% Bromelain with $50 \%$ Papain. with the results of test, namely: dissolved protein $17,447 \%$, water content $71,781 \%$, free fatty acid (ffa) $1,941 \%$, total plate count $4.6 \times 106 \mathrm{cfu}$, ph value 5,420, butyric acid 2,767 \%, acetic acid 1,810 \% and lactic acid 2,720\% and organoleptic favored by consumers.
\end{abstract}

International Journal of Life Sciences (C) 2020. This is an open access article under the CC BY-NC-ND license (https://creativecommons.org/licenses/by-nc-nd/4.0/).

\section{Contents}

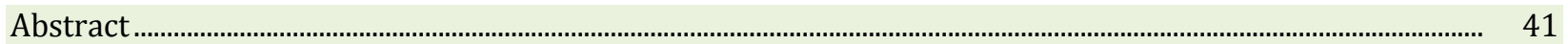

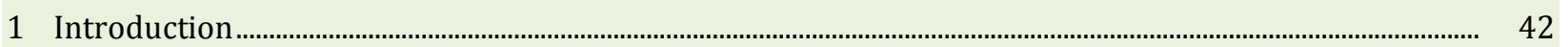

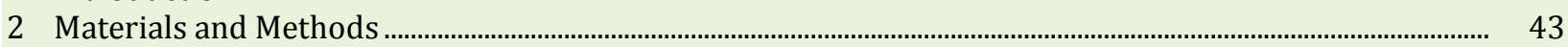

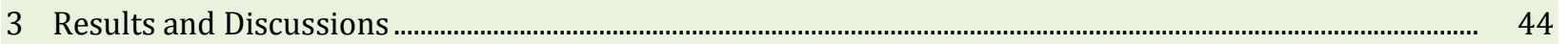

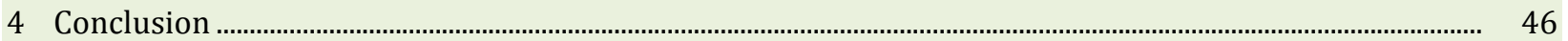

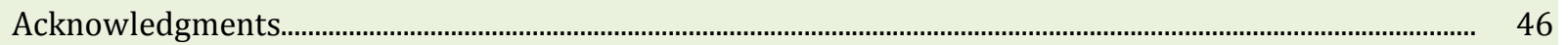

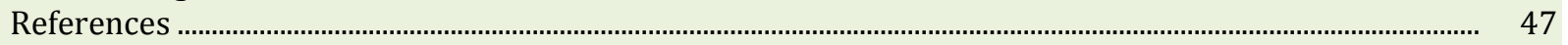

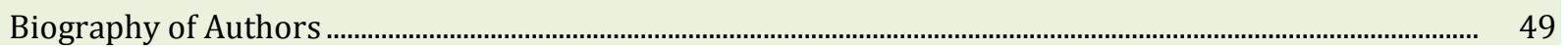

a Aquatic Resources Management Study Program, Warmadewa University, Denpasar, Indonesia

b Aquatic Resources Management Study Program, Warmadewa University, Denpasar, Indonesia

c Aquatic Resources Management Study Program, Warmadewa University, Denpasar, Indonesia 


\section{Introduction}

Fish has high enough protein, as said by Suryaningrum et al. (2010), that fish protein ranges from 12.94 $17.52 \%$ including high, besides that fish contains long-chain unsaturated fatty acids, especially those containing omega 3 fatty acids which can reduce the number of triglycerides, lower cholesterol levels in the blood and can increase fat metabolism (Wally et al., 2015). To increase the people's attractiveness to fish consumption, there is a need for innovation in food diversification. Food diversification efforts can be carried out by looking for new foodstuffs or ingredients from existing foods and developed into diverse foodstuffs (Setyaningsih \& Saputra, 2011 in Muthmainna et al., 2016).

Tongkol (Euthynnus affinis) is a fish that is present in the market, almost no season, meaning that it is always available every day (Results of a survey by researchers in several traditional markets). There are very limited types of tuna processed in the market, Fermentation Technology can be selected to diversify Tongkol fish processing. Fermentation extends the definition to all processes that involve microorganisms to produce a product called primary and secondary metabolites in a controlled environment and then develop again into the whole transformation of organic compounds carried out by microorganisms (Jannah, 2010). The role of lactic acid bacteria, in this case, is to improve the taste of fermented products and also has a preservative effect because it can produce compounds that can inhibit the growth of various microbes. Much of this antimicrobial effect is due to the build-up of lactic and acetic acids and the resulting drop in pH (De Vuyust \& Vandamme, 1994 in Kusumawati, 2012).

The purpose of this research is the creation of fermentation technology for tuna fish which has the best Organoleptic and Biochemical Value. The benefits of this research are aimed at several related Steak Holders such as: For the academic field as information material. For fishery fish processors, it can be used as new processing, for tongkol fish.

\section{Literature Review}

Description and classification of tongkol fish

Tongkol fish including pelagic fish, have a torpedo shape so that they are classified as fast swimmers and live in groups. Tongkol is a large pelagic because it has a size of about $20 \mathrm{~cm}$, which is small if it has a size less than $10 \mathrm{~cm}$ and medium size is between $10 \mathrm{~cm}-20 \mathrm{~cm}$ (Hadiwiyoto, 1993). According to Suzuki (1981) in Yuwono (2015), Tongkol meat structure consists of red meat that contains $71-76.7 \%$ water, $21.6-26.3 \%$ protein, and $1.3-2.1 \%$ fat. Furthermore, the Classification of Tuna Fish (Euthynnus affinis) is as follows:

$\begin{array}{ll}\text { Phylum } & \text { : Chordata } \\ \text { Class } & \text { : Teleostei } \\ \text { Ordo } & \text { : Perchomorphi } \\ \text { Sub Ordo } & : \text { Scombridae } \\ \text { Familiy } & \text { : Scombridae } \\ \text { Genus } & \text { : Euthynnus } \\ \text { Species } & \text { : Euthynnus affinis }\end{array}$

\section{Fermentation}

Fermentation technology is a technology that makes effective use of microbial activities that are beneficial to humans. Today's fermentation technology has been applied to the pharmaceutical industry, producing chemicals, manufacturing enzymes, and others (Yopi, 2004; Nout et al., 1989; Ando et al., 1986; Steinkraus, 1997). Fermentation is a simple transformation of raw materials into products that have added value by using the phenomenon of microorganism growth and their activities on various substrates. This means that knowledge of microorganisms is important for understanding the fermentation process (Prajapati \& Nair, 2003 in Desniar, 2012).

Fermentation in fish is a process of breaking down complex compounds contained in the fish body into simpler compounds by enzymes or fermentation originating from the fish body itself or microorganisms that take place under controlled environmental conditions (Afrianto \& Liviawaty, 1989). The enzymes in fish will 
break down fish protein into simpler units and also suppress pathogenic bacteria (Yuniarti et al., 2002). Lactic acid bacteria (LAB) is a type of bacteria that is capable of producing lactic acid as an end product of its metabolic process. LAB uses carbohydrates as a source of nutrition for metabolic processes (Yuniati Fajri et al., 2014).

\section{Materials and Methods}

The research was carried out in two places, namely the Laboratory of the Faculty of Agriculture, Warmadewa University, for the place of product manufacture, TPC analysis, $\mathrm{pH}$, analysis of moisture content, and organoleptic analysis. 3. Laboratory of Food Analysis, Faculty of Agricultural Technology, Udayana University for chemical analysis (Free Fatty Acid Analysis, Dissolved Protein Analysis, Research time is planned for 8 months starting from the preparation of product production. The material used is Euthynnus affinis, a set of chemicals used for TPC analysis, Free Fatty Acid Analysis, Dissolved Protein, Water Content, organoleptic. The equipment used is equipment for TPC analysis, free fatty acid analysis. Moisture content and Organoleptic analysis

This study using a completely randomized design experimental method with a single factor, namely the use of three types of ferment. The three types of Fermen used are A = Bromelain Enzyme (Fresh Pineapple Fruit), B = Papain Enzyme (Fresh young papaya fruit), and the third C $=50 \%$ Bromelain with 50\% Papain. Repeat 3 times, after it tabulated the data, analyzed the data statistically using ANOVA with further tests using BNT (Least Significant Difference). Research implementation:

1) Preparing homogeneous tuna. Prepare three types of ferment that will be used: Pineapple Fruit, Papaya Fruit, Combination of 50\% Pineapple Fruit and 50\% Papaya

2) Prepare all tools and research support materials, research according to treatment

3) Perform fermentation for four (4) days, Analyze Samples. Data tabulation and data analysis.

Research flowchart can be seen in Figure 2:

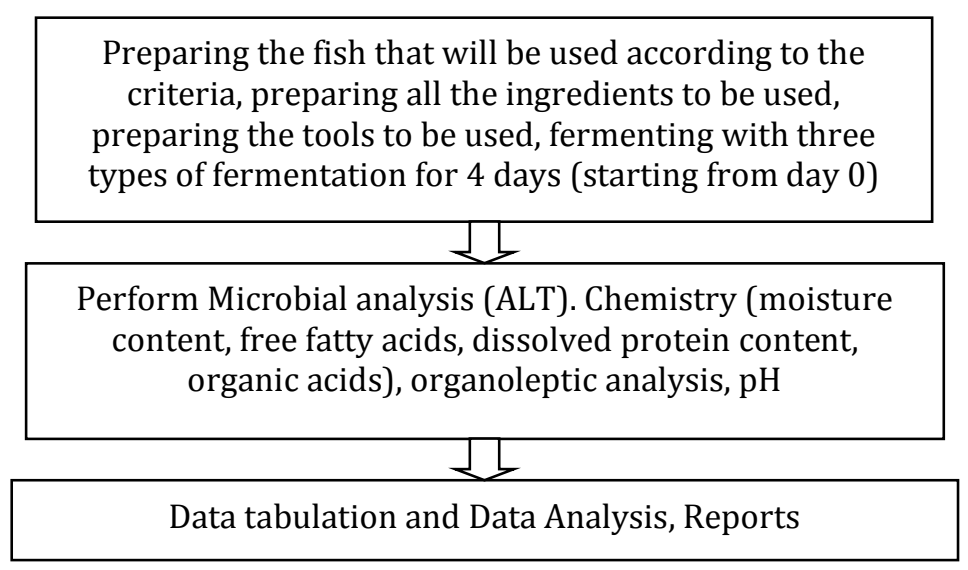

Figure 2. Flowchart of research implementation

The procedure for determining the analysis for all variables has met the SNI. Determination of moisture content, free fatty acids, analysis of organic acids, analysis of dissolved protein (spectronic) (Sudarmadji \& Haryono, 1997), Microbiological analysis with TPC / Total Plate Count, Organoleptic analysis by describing objects. The data obtained from the results of the study were then processed by ANOVA with the LSD further test. (Smallest Significant Difference) to see the effect between treatment units.

Darmadi, N. M., Semara, D. G. \& Kawan, I. M. (2020). Tongkol (Euthynnus affinis) fermentation on organoleptics and its biochemistry. International Journal of Life Sciences, 4(3), 41-49. https://doi.org/10.29332/ijls.v4n3.503 


\title{
3 Results and Discussions
}

\author{
Chemical Test
}

Table 1

Average parameter test value

\begin{tabular}{lllllllll}
\hline Factor & $\begin{array}{l}\text { Dissolved } \\
\text { Protein } \\
(\%)\end{array}$ & $\begin{array}{l}\text { Dissolved } \\
\text { Protein } \\
\%)\end{array}$ & $\mathrm{pH}$ & $\begin{array}{l}\text { FFA } \\
(\%)\end{array}$ & $\begin{array}{l}\text { cutyric } \\
\text { Acid } \\
(\%)\end{array}$ & $\begin{array}{l}\text { Acetic acid } \\
(\%)\end{array}$ & $\begin{array}{l}\text { Lactic acid } \\
(\%)\end{array}$ & $\begin{array}{l}\text { Colony TPC } \\
\text { test/gram }\end{array}$ \\
\hline A & 17.917 & 71.368 & 5.520 & 2.722 & 2.910 & 1.980 & 2.970 & $2.5 \times 10^{5}$ \\
B & 17.230 & 72.517 & 5.364 & 1.537 & 1.933 & 1.310 & 1.970 & $6.3 \times 10^{6}$ \\
C & 17.447 & 71.781 & 5.420 & 1.941 & 2.767 & 1.810 & 2.720 & $4.6 \times 10^{6}$ \\
Fresh fish & 17.22 & 75.286 & 5.645 & 0.973 & 0.95 & 0.64 & 0.97 & $1.9 \times 10^{7}$ \\
\hline
\end{tabular}

1) Dissolved Protein Test

Judging from the Anova test on the fermented tuna (Euthynnus affinis) dissolved protein test, it turns out that the treatment has no real effect. When compared with the value of fresh tuna fish dissolved protein (17.22\%) increased after fermentation to 17,917 (A), 17,210 (B), and 17,447 (C). This shows that fermentation can increase the value of Tongkol fish dissolved protein, only the three ferments have no significant effect on the dissolved protein value. Following the opinion Illanes (2008) in Utami et al. (2011) that Bromelin is included in the protease group produced from pineapple extraction which can hydrolyze the connective tissue of the meat, including degrading meat collagen so that it can open the microstructure of the meat by breaking off myofibrils which can soften the meat so that more dissolved protein is detected. For ferment, papain includes proteases that are active on vegetable protein so that less dissolved protein is detected.

2) Test Moisture Content

After analyzing with ANOVA, it turns out that the treatment has a very significant effect on the water content value of fermented cob (Lindawati et al., 2018). The highest water content value was obtained in treatment B $(72,517)$ followed by Treatment $C(71,781)$ and the smallest was treatment $A(71,368)$ and from the Notation treatment, $A$ and $C$ had the same notation. There was a decrease in the value of water content when compared to the water content of fresh tuna $(75.286 \%)$. The lowest water content value was obtained in tuna fish with ferment Bromelin because bromelin works more actively on animal protein so that more water release occurs (Liu et al., 2008; DeVitre \& Cunningham, 1985). While the papain enzyme works more actively on the vegetable protein (Winarno 1995 in Taqwdasbrilian et al., 2013) so that the water content is higher.

3) $\mathrm{pH}$ test

After ANOVA analysis was carried out, it turned out that the treatment had no significant effect on the $\mathrm{pH}$ value of fermented tuna. The pH values from large to small were A $(5,520), \mathrm{C}(5,420)$, and B $(5,364)$, respectively, with the same notation for the three treatments. There was a decrease in $\mathrm{pH}$ when compared to fresh tuna, namely 5,645. The decrease in $\mathrm{pH}$ is thought to be due to the formation of organic acids such as lactic acid produced by lactic acid bacteria in their metabolism so that the $\mathrm{pH}$ of the media becomes acidic (Desniar \& Wijatur, 2009). The more organic acids are formed, the lower the pH will be.

4) Free Faty Acid (FFA)

In this study, the treatment gave a very real effect on the value of free fatty acids in tuna. In order from large to small, the Free Fatty Acid value due to treatment is A (2.722, C (1.941), and the smallest is C 
1.577). There was an increase in free fatty acids when compared to free fatty acids in fresh tuna (0.973\%). Free fatty acids are a measure of fat that has undergone an overhaul. In fermentation, the role is Lactic Acid Bacteria which will convert organic matter into simpler compounds including the conversion of fats into fatty acids and glycerol. Free Fatty Acids are a part of Fatty Acids (Marchetti et al., 2007; Nilsson et al., 2003). The overhaul of fat into a simpler element will make a distinctive taste in fermented products. Fat reduction will occur in fermented food because fat is converted into volatile and non-volatile fatty acids which will form the taste of food (Aryanta, 1994 in Putri et al., 2014).

5) Test Total Plate Number (ALT) Bacteria (cfu)

Table 2

Data for Total Plate Figures (ALT)

\begin{tabular}{|c|c|c|c|c|c|}
\hline \multirow{2}{*}{ Factor } & \multicolumn{3}{|c|}{ Deuteronomy } & \multirow{2}{*}{ Total } & \multirow{2}{*}{ Average (cfu) } \\
\hline & 1 & 2 & 3 & & \\
\hline A & $2.4 \times 10^{5}$ & $2.8 \times 10^{5}$ & $2.3 \times 10^{5}$ & $7.5 \times 10^{5}$ & $2.5 \times 10^{5}$ \\
\hline B & $6.1 \times 10^{6}$ & $6.4 \times 10^{6}$ & $6.4 \times 10^{6}$ & $18.9 \times 10^{6}$ & $6.3 \times 10^{6}$ \\
\hline $\mathrm{C}$ & $4.6 \times 10^{6}$ & $4.5 \times 10^{6}$ & $4.7 \times 10^{6}$ & $13.8 \times 10^{6}$ & $4.6 \times 10^{6}$ \\
\hline
\end{tabular}

The total plate count test is described as descriptively. In general, there is a decrease in the number of bacteria. Turn from small to large occurred in the treatment: A ( $2.5 \times 105), \mathrm{C}$ (4.6 x 106), B) 6.3x 106). This is related to the $\mathrm{pH}$ value of the treatment. There was a decrease in $\mathrm{pH}$ during fermentation. this condition makes the bacteria live in stress. so that the number of bacteria decreases. The use of salt also results in a decrease in the number of bacteria.

The results of research by Desniar \& Wijatur (2009), show that the number of log bacteria decreased from fermentation to 0-6 due to the role of salt added in the treatment, because salt can select microbes, and after 6 to 14 days There is an increase in the number of bacteria because at this time lactic acid bacteria are starting to grow. In this study, fermentation was carried out for 3 days so that it was natural that the number of bacteria decreased.

6) Test for Lactic Acid, Acetic acid, Butyric Acid

In fermentation products, organic acids will always be formed which is the result of the activity of Lactic Acid Bacteria. The results showed that the treatment had a very significant effect on the formation of lactic acid, acetic acid, and butyric acid. The value of lactic acid, acetic acid, and butyric acid can be seen in Table 5.1. It can be seen that there is an increase in the value for the three types of organic acids above when compared to the value of organic acids in fresh tuna.

Types of Lactic Acid Batteries found in fermented Cob is heterofermentative, it is proven that organic acids other than lactic acid and lactic acid do not dominate the amount in this treatment. The fermentation process is homofermentative if it only produces lactic acid or which dominates it. According to Afriani (2010) in Dali (2014), fermentation is heterofermentative to produce a mixture of various compounds or other components, for example, acetate, ethanol, carbon dioxide, and lactic acid, it is also said that fermentation can grow acid-forming microbes and alcohol and suppress growth. proteolytic and lipolytic microbes

Darmadi, N. M., Semara, D. G. \& Kawan, I. M. (2020). Tongkol (Euthynnus affinis) fermentation on organoleptics and its biochemistry. International Journal of Life Sciences, 4(3), 41-49. https://doi.org/10.29332/ijls.v4n3.503 
7) Organoleptic Test
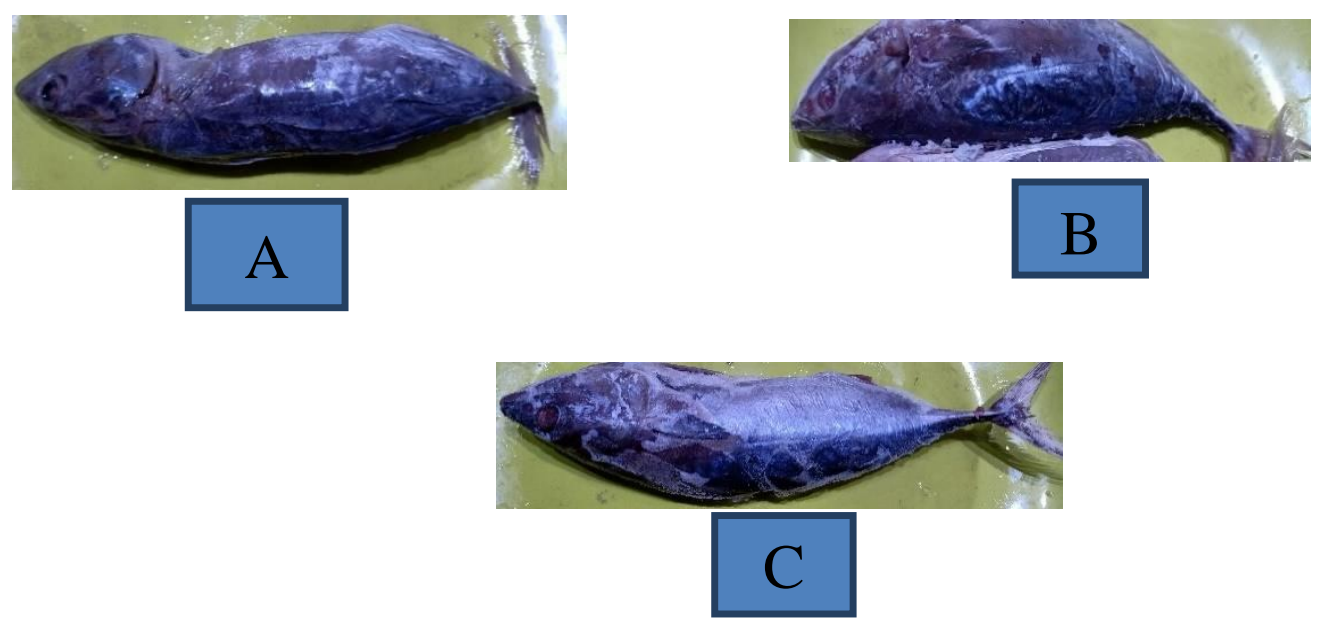

Figure 3. Organoleptic test

The fermented cob organoleptic test was described descriptively. The results showed that the appearance of fermented cobs with different ferments gave different results. The most preferred appearance by consumers is fermented tuna using a combination of $50 \%$ Bromelain and $50 \%$ papaya (C) ferment. This happens because the fish looks intact, there are no parts that are loose and the color is like fresh fish. The use of fermented Bromelin (A) Fermented tuna has a characteristic, the eyes and gills of the fish appear loose because Bromelain is an active ferment for animals so that it decomposes at a fast rate, which results in the fish's eyes and gills being released. Using papaya ferment shows the appearance of fermented cobs is slightly brown but the eyes and gills do not come off.

\section{Conclusion}

From the results of the study it can be concluded that the best fermented that can be used as fermented for making fermented tuna (Euthynnus affinis) is Treatment C, namely: Combination of $50 \%$ Bromelain (Pineapple) with 50\% Papain (Papaya) with Value: 17.447\% Dissolved Protein, Water Content 71,781, Free Fatty Acid (FFA) 1,941, Total Plate Number 4.6x106 cfu, pH value 5,420, Butyric Acid 2,767, Acetic Acid 1,810 and Lactic Acid 2,720 and Organoleptic Favored by consumers

\section{Acknowledgments}

We are grateful to two anonymous reviewers for their valuable comments on the earlier version of this paper. 


\section{References}

Afriani, A. (2010). Pengaruh penggunaan starter bakteri asam laktat lactobacillus plantarum dan lactobacillus fermentum terhadaptotal bakteri asam laktat, kadar asam dan nilai pH dadih susu sapi. Jurnal Ilmiah IlmuIlmu Peternakan, 279-285.

Afrianto, I. E., \& Liviawaty, I. E. (1989). Pengawetan dan pengolahan ikan. Kanisius.

Ando, S., Arai, I., Kiyoto, K., \& Hanai, S. (1986). Identification of aromatic monomers in steam-exploded poplar and their influences on ethanol fermentation by Saccharomyces cerevisiae. Journal of fermentation technology, 64(6), 567-570. https://doi.org/10.1016/0385-6380(86)90084-1

Aryanta, W. R. (1994). Lactid Acid Fermented Fish Product. Majalah Chemic Unud, 21(42), 10-15.

Dali, F. A. (2014). Karakterisasi Bakteri Asam Laktat yang Diisolasi Selama Fermentasi Bakasang. Jurnal Pengolahan Hasil Perikanan Indonesia, 16(2).

Desniar, P. D., \& Wijatur, W. (2009). Pengaruh konsentrasi garam pada peda ikan kembung (Rastrelliger sp.) dengan fermentasi spontan. Jurnal Pengolahan Hasil Perikanan Indonesia, 12(1), 73-87.

Desniar. (2012). Karakterisasi Bakteri Asam Laktat Dari Produk Fermentasi Ikan (Bekasam). Disertasi. Program Studi Mikrobiologi Sekolah Pascasarjana Institut Pertanian Bogor.

DeVitre, H. A., \& Cunningham, F. E. (1985). Tenderization of spent hen muscle using papain, bromelin, or ficin alone and in combination with salts. Poultry Science, 64(8), 1476-1483. https://doi.org/10.3382/ps.0641476

Hadiwiyoto, S. (1993). Teknologi pengolahan hasil perikanan. Liberty.

Illanes, A. (2008). Enzyme biocatalysis. Principles and Applications. Editorial Springer-Verlag New York Inc., United States, 1-56.

Jannah, A. M. (2010). Proses fermentasi hidrolisat jerami padi untuk menghasilkan bioetanol. Jurnal Teknik Kimia, 17(1).

Kusumawati, N. (2012). Peranan bakteri asam laktat dalam menghambat Listeria monocytogenes pada bahan pangan. Jurnal teknologi pangan dan gizi, 1(1).

Lindawati, S. A., Mahardika, G., Suardana, I. W., \& Antara, N. S. (2018). Inhibition activities of angiotensin converting enzyme and amino acid kefir whey profile of skim milk fermented by kefir grains. International research journal of engineering, IT \& scientific research, 4(5), 17-25.

Liu, Z., Dong, S., Xu, J., Zeng, M., Song, H., \& Zhao, Y. (2008). Production of cysteine-rich antimicrobial peptide by digestion of oyster (Crassostrea gigas) with alcalase and bromelin. Food Control, 19(3), 231-235. https://doi.org/10.1016/j.foodcont.2007.03.004

Marchetti, J. M., Miguel, V. U., \& Errazu, A. F. (2007). Heterogeneous esterification of oil with high amount of free fatty acids. Fuel, 86(5-6), 906-910. https://doi.org/10.1016/j.fuel.2006.09.006

Muthmainna, M., Sabang, S. M., \& Supriadi, S. (2016). Pengaruh Waktu Fermentasi Terhadap Kadar Protein Dari Tempe Biji Buah Lamtoro Gung (Leucaena leucocephala). Jurnal Akademika Kimia, 5(1), 50-54.

Nilsson, N. E., Kotarsky, K., Owman, C., \& Olde, B. (2003). Identification of a free fatty acid receptor, FFA2R, expressed on leukocytes and activated by short-chain fatty acids. Biochemical and biophysical research communications, 303(4), 1047-1052. https://doi.org/10.1016/S0006-291X(03)00488-1

Nout, M. R., Rombouts, F. M., \& Havelaar, A. (1989). Effect of accelerated natural lactic fermentation of infant good ingredients on some pathogenic microorganisms. International journal of food microbiology, 8(4), 351-361. https://doi.org/10.1016/0168-1605(89)90006-8

Prajapati, J. B., \& Nair, B. M. (2003). Handbook of fermented functional foods.

Putri, D.M., Budiharjo, A.,Kusdiyantini, E. (2014). Isolasi, Karakterisasi Bakteri Asam Laktat, Dan Analisis Proksimat Dari Pangan Fermentasi Rusip Ikan Teri (Stolephorus Sp.) Jurnal Biologi, Volume 3 No 2, April 2014 Hal. 11-19 Jurusan Biologi, Fakultas Sains dan Matematika, Universitas Diponegoro.

Setyaningsih, I., \& Saputra, A. T. (2011). Komposisi kimia dan kandungan pigmen Spirulina fusiformis pada umur panen yang berbeda dalam media pupuk. Jurnal Pengolahan Hasil Perikanan Indonesia, 14(1).

Steinkraus, K. H. (1997). Classification of fermented foods: worldwide review of household fermentation techniques. Food Control, 8(5-6), 311-317. https://doi.org/10.1016/S0956-7135(97)00050-9

Sudarmadji, S., \& Haryono, B. (1997). Suhardi. Analisa Bahan Makanan dan Pertanian, 96-114.

Suryaningrum, T. D., Muljanah, I., \& Tahapari, E. (2010). Profil sensori dan nilai gizi beberapa jenis ikan patin dan hibrid nasutus. Jurnal Pascapanen dan Bioteknologi Kelautan dan Perikanan, 5(2), 153-164.

Darmadi, N. M., Semara, D. G. \& Kawan, I. M. (2020). Tongkol (Euthynnus affinis) fermentation on organoleptics and its biochemistry. International Journal of Life Sciences, 4(3), 41-49. https://doi.org/10.29332/ijls.v4n3.503 
Taqwdasbrilian, E.B., Hutabarat, Y., Arini, E. (2013). The Effect Of Combination Papain Enzyme And Bromelain Enzyme On The Feed Utilization And Growth Rate Of The Grouper (Epinephelus Fuscogutattus). Journal Of Aquaculture Management And Technology 2(3), 76-85. Program Studi Budidaya Perairan Jurusan Perikanan, Fakultas Perikanan Dan Ilmu Kelautan, Universitas Diponegoro.

Utami, D. P., Pudjomartatmo, P., \& Nuhriawangsa, A. M. P. (2011). Manfaat bromelin dari ekstrak buah nanas (Ananas comosus L. Merr) dan waktu pemasakan untuk meningkatkan kualitas daging itik afkir. Sains Peternakan: Jurnal Penelitian Ilmu Peternakan, 9(2), 82-87.

Wally, E., Mentang, F., \& Montolalu, R. I. (2015). Kajian mutu kimiawi ikan cakalang (Katsuwonus pelamis L.) asap (FUFU) selama penyimpanan suhu ruang dan suhu dingin. Media Teknologi Hasil Perikanan, 3(1).

Winarno, B. (1995). Shrimp aquaculture in Indonesia. In Swimming through troubled water, Proceedings of the special session on shrimp farming, Aquaculture'95. World Aquaculture Society.

Yopi. (2004). Teknologi Fermentasi (Pemanfaatan Mikroba dalam Kehidupan). Warta Sains dan Teknologi ISTECS- japan.

Yuniarti, A., Hariati, A. M., \& Sanoesi, E. (2002). Teknologi silase dengan starter bakteri asam laktat untuk pertumbuhan dan deposisi protein ikan lele dumbo (Clarias gariepinus). Jurnal Ilmu-Ilmu Hayati, 14(1), 42-49.

Yuniati Fajri, A. A., \& Rasmi, D. A. C. (2014). Fermentasi Ikan Kembung (Rastrelliger sp.) dalam Pembuatan Peda dengan Penambahan Bakteri Asam Laktat (BAL) yang Terkandung dalam Terasi Empang pada Berbagai Konsentrasi Garam. Jurnal Biologi Tropis, 14(2).

Yuwono, S.S. (2015). Ikan Tongkol (Euthynnus affinis) 


\section{Biography of Authors}

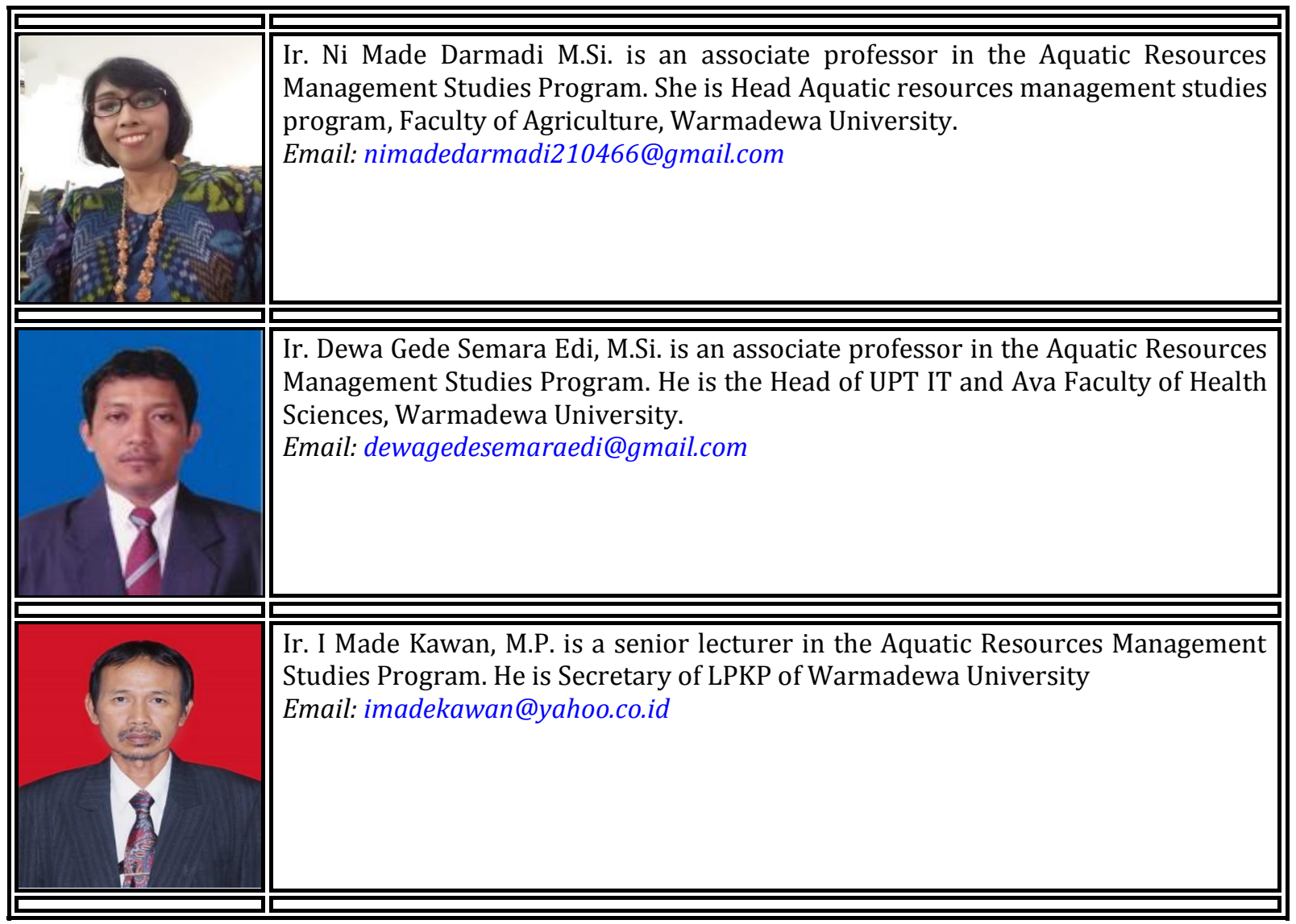

Darmadi, N. M., Semara, D. G. \& Kawan, I. M. (2020). Tongkol (Euthynnus affinis) fermentation on organoleptics and its biochemistry. International Journal of Life Sciences, 4(3), 41-49. https://doi.org/10.29332/ijls.v4n3.503 